\title{
Mechanisms of Conflict Management in Tanzania's Local Government Authorities: A Case of Bukoba Municipal Council
}

\author{
Venance Shillingi Salum \\ Mzumbe University, School of Public Administration and Management. \\ E-mail: sshtzone@gmail.com
}

Received: August 14, 2017 Accepted: September 5, 2017 Online published: September 10, 2017 doi:10.5296/jpag.v7i3.11681

URL: https://doi.org/10.5296/jpag.v7i3.11681

\begin{abstract}
Conflict management influences individual wellbeing, group performance and organizational effectiveness. The study was set out to investigate ways of managing conflicts between councilors and employees in Tanzania's local Government authorities with particular reference to Bukoba Municipal Council. It also investigated mechanisms used to solve conflicts between councilors and employees of Bukoba Municipal Council. In this study, both quantitative and qualitative research approaches were used; and the result indicates that, there are conflict between councilors and employees which arise due to different level educations, delay in project implementation, personal interests, scarcity of resources and negative attitude, interference on duties between councilors and employees at BMC. Also, the respondents revealed that, conflicts between councilors and employees had negative effects to Bukoba Municipal Council, such as delay in project implementation, low morale, resignation of potential employees, and increases of unnecessary costs. Moreover, different mechanisms were used to solve conflicts between councilors and employees, among others, were through mediation, negation, meetings, collective bargaining and accommodation.
\end{abstract}

Keywords: Tanzania, Local government authorities, conflicts, conflict management, and conflict resolutions.

\section{Introduction}

Conflict can be defined as the behavior by a person or group intended to inhibit the attainment of goals by another person or group (Hughes, 2001). This is typically an irreconcilable contention between two or more parties. Moreover, organizational conflict is a state of discord caused by the actual or perceived opposition of values; needs and interests between people working together. Also, Human beings have been in conflict since the very 
beginning of history, but the beginning of conflict can be said to be when the popular and remarkable conflict that brought attention to many people working in different industries. This situation stimulated the commencement of Industrial Revolution of the 1800's in Europe and in the United States, this conflict was not a conflict of itself, but created problems between social classes hence presaged the beginning of organizational conflict (Clarke, 1999). Historically, local government authorities are characterized by conflicts and misunderstandings between councilors and permanent employees; this kind of situation facilitated to failure of local government authorities to achieve its goals (Kunkuta, 2003). The Bukoba Municipal Council being one of local government authorities in Tanzania is of no exception when it comes to the management of conflicts. Conflicts are unavoidable as far as are people have got different stands, ideals, perceptions, levels of education and beliefs; and due to that reason, an organization should use proper ways of managing conflicts so as to avoid its negative impact to organization.

\section{Literature Review}

\subsection{Types of Conflict}

There are different types of conflict that can occur in the workplace. Conflicts can occur as a result of conflicting choices in procedure or because two people want different things. Conflicts can occur because of changes in an organization. Also, conflict arises at different levels or types depend on the name, which the authors choose to use to call these levels. According to Darling \& Walker, (2001), the most commonly observed conflict in organization can be classified as follows: -

\subsubsection{Inter-personal Conflict}

Inter-personal conflict, this kind of conflict takes place between two or more individual and it is the most common in organization, this because of difference in perception, goal, attitude, values, personality clashes, and competitiveness are the primary source of interpersonal conflict

\subsubsection{Inter Group Conflict}

Inter group conflict, intergroup conflict is more evident when organization structure itself increases the interdependence among groups, since different groups will have incompatible goals, and different groups may compete for scarce resources, intergroup are more visible in organization

\subsubsection{Conflict between an Organization and a Prevailing Work Environment}

Conflict between an organization and a prevailing work environment, to copy with the competitive pressure, organizations are compelled to adopt a new work culture departing from their age practices. This create conflict between organization and organization practices, which at its extreme stage, lead to major organization issues such as high rate of attrition, employee unrest, and major industrial relation problems. 


\subsection{Causes/Sources of Conflict}

Change is a main reason that there is conflict in the workplace. One of the most challenging obstacles for an employee to try to overcome is change. Change comes in many different ways. The employee may have to adjust to new rules, new management, and new location, where employee may refuse to break old habits and adjust to new set of guidelines. All of these changes can and will create conflict in any work environment (Ibid). Furthermore, our age plays a major role, according to Jaffee (2008). He stated that, "The older we get the more we appreciate predictability in our lives. We like to know that we will show up at work and see the same people, work at the same station, and perform a function that is familiar to us." He went on to say that, changes remove the predictability most of us are used to and because of that we encounter a great deal of distress (Darling \& Walker, 2001), try to give out other different source or cause of conflict which a best understood as follows.

i. Need based conflict, this is due to that employee differ in their perceived needs, hence depend on the varied nature of needs, conflict will due to multiplicity of need, incongruence of needs, need dissatisfaction and dilemma of the choice

ii. Working environment, also work environment is source of conflict due to job roles of individual employees, their job interaction, line, and staff conflict

iii. Organization factors, often organization factors such as authority and responsibility, excessive or low standardization, transfer, communication and scarcity resources.

iv. Goals incompatibility, also conflict arises due to the differences in goals and objectives, to both side between individuals and between individual and organization, this kind of conflict could be win-win conflict, lose -lose conflict win-lose conflict.

v. Individual factors, also people differ themselves in term of their culture, education, status, ideology, attitude, experiences, competition, such difference will be the source of conflict to them

\subsection{Productive and Non-productive Sides of Conflict}

According to (Newton, 2002), conflict can be constructive due to benefit which it produces such as energizing them to be more creative and to experiment with new ideas, also people are stimulated to search for improved approach that lead to better result. Another benefit is that when hidden problems are brought to the surface, where they may be confronted and solved. Moreover, Participants often see conflict as destructive; this is limited view, (Newton 2002). In fact, if all conflict with workers is avoided, each party is likely deprived of useful information about the other's preferences and views. A more positive view then is to see that conflict is nearly inevitable and to search for ways in which it can result to productive. Further, in other side conflict can be destructive due it disadvantages brought such as if the conflict stays long in the organization it allows to focus on personal issues. Distrust may grow among people who need to coordinate their effort, also at individual level some people will feel as defeated, self-image of other will decline and person stress level will rise. 


\subsection{Ways of Managing Conflict}

Conflict management is the process of avoiding conflict, Pondy, (2009), continues by saying that, resolve conflict in real basis. The conflict isn't the problem - it is when conflict is poorly managed, that is when becomes the problem. According to (Mishra, 2001), conflict can be managed effectively through managing organization behavior, developing an appropriate organizational structure and adopting the system and process cooperative culture. Conflict management is responding to problems stemming from conflict (Clarke, 1999). There are five basic methods to dealing with conflicts. These include avoidance, accommodation, compromise, competition, and collaboration. Once managers have an understanding of these methods, can adjust their strategy to resolve conflicts by choosing the right method for the right situation.

\subsubsection{Avoidance}

Some people attempt to avoid conflict by postponing it, hiding their feelings, changing the subject, leaving the room or quitting the project. Avoidance usually does not help to solve the problem; it just postpones the problem for another day. However, avoidance can actually be a good idea when it is a small matter not worth disrupting the harmony of the workplace over or when we need to calm down before addressing the issue.

\subsubsection{Accommodation}

Accommodation is a convenient strategy to satisfy an immediate need for individuals or the group. It emphasizes the things conflicting parties have in common while de-emphasizing the differences. This method helps the people to focus on the current issues and put differences aside till a later time. It is slightly more effective than mere avoidance as finding common ground helps to prevent lingering ill will more simply than avoiding an argument.

\subsubsection{Compromise}

Compromise is a technique where by the opposing parties in a conflict make concessions to each other in order to peacefully resolve the issue. It can be effective when each side is willing to negotiate and settle for less than they originally wanted, but falls apart if the demands of each side are too great or neither side honours their end of the bargain.

\subsubsection{Competition method}

Competition method is basically finding a way to resolve the issue other than fighting or arguing. Some contests where the winner gets his or her demands met. It can be used to resolve a conflict, but often causes cooperation to deteriorate, so it is best used as a last resort.

\subsubsection{Collaboration}

Collaboration is when the opposing parties decide to put aside their differences and work together to accomplish the objective in a manner that satisfies everyone. This strategy encourages teamwork and cooperation within a group. This is most effective when the members of the group respect and trust each other, and are willing to remain open-minded. Unfortunately, these are ideal conditions, and not all groups will have such defined unity. 
However, deciding which method to employ requires an understanding of the conflict in order to choose the best possible solution. (Greenberg, 1999) try to review two most popular techniques used to manage conflict in organization that are explained below;

\subsubsection{Bargaining}

Bargaining is the process in which two or more parties in disputes with each other exchange offers, counteroffers, and concession in an attempt to find a mutually acceptable agreement. When conflict arises between individual, groups, or even entire organization, the most common ways to resolve them is to negotiate a solution that is acceptable to all parties. In order bargaining to be effective, the parties involved must be willing to adjust their stances on issue as at hand and for the people involved to be willing to make such adjustment, they must believe that, they found an acceptable outcome which allow them to claim victory in the negotiation process.

\subsubsection{Third-party Intervention}

Third-party Intervention, sometimes there is deadlock that occurs when negotiation solution between the parties with conflict interests do not reach consensus. The effective means used to break that deadlock is to use third parties' individuals who are not involve in conflict but called upon to intervene in interest of finding solution. The commonly used type of the third party is mediation. The third parties try to create voluntary agreement between disputants.

\subsection{Conflict Management Theories}

Conflict management is what people who experience conflict intend to do as well as what they actually do (Johson, 2004). Although an infinite number of conflict management strategies may be conceived of, conflict research and theory tends to converge on Dual Concern Theory (Robbins and Sanghi, 2006).

\subsubsection{Dual Concern Theory}

Dual Concern Theory argues that, conflict management is a function of high or low concern for self, combined with high or low concern for others. High concern for self and low concern for others results in a preference for forcing, focused on imposing one's will on others (Robbins and Sanghi, 2006). Forcing involves threats and bluffs, persuasive arguments, and positional commitments. Low concern for self and high concern for others results in a preference for yielding, which is oriented towards accepting and incorporating others will. It involves unilateral concessions, unconditional promises, and offering help. Low concern for self and others results in a preference for avoiding, which involves reducing the importance of the issues, and attempts to suppress thinking about the issues. High concern for self and others produces a preference for problem solving, which is oriented towards an agreement that satisfies both own and others' aspirations as much as possible (Ibid).

\subsubsection{Two-dimensional Conflict Behaviour Model}

Blake and Mouton developed a two-dimensional conflict behavior model that is still referenced today. The two-dimensional model of conflict includes: assertiveness, defined as a 
party's attempt to satisfy his own concerns, and cooperativeness, defined as attempts to satisfy the concerns of another person (Pareck, 2002). Darling \& Walker, (2001), however, suggested that conflict could be classified as functional (means impact to organization not individual) or dysfunctional based on how the conflict affects an organization's performance. However, Conflict has positive as well as negative consequences on organization if that difference is impersonally treated and discussed on common platform the conflict will give positive result (Mishran, 2001). Positive impact of conflict such as energizing them to be more creative and to experiment with new ideas and negative effect like facilitate failure of organization to achieve its goals effectively. In this regard, conflicts in organizations like local government authorities are inevitable, and have both positive and negative impacts to the organization performance; and hence sometimes conflicts are referred as health of any organization, as no organization is free from conflicts if it has to grow and turn around its vision into reality.

\section{Methodology of the Study}

\subsection{Research Context}

The area of the study was Bukoba Municipal Council, one of the council among nine (9) councils in Kagera region. The area was purposely selected due to availability of different conflicts which involved councilors and employees, the mayor and councilors, and sometimes, the members of parliament and the mayor of the municipal council.

\subsection{Sampling and Sampling Procedure}

The target populations of the study involved employees (particularly Heads of departments, units, and sections) of the Bukoba Municipal Council, the Municipal Director (MD), and councilors. The study used purposive sampling to select Municipal Director and the Mayor of Bukoba Municipal Council; and random sampling was used to select 35 respondents from employees who comprised 58-target population, including heads of departments (14), heads of units (4) and heads of sections (40). Also, random sampling was used to select 13 councilors out of 23 councilors of Bukoba Municipal council (these comprised 14 councilors elected from 14 wards in the municipality, 3 members of parliament, 6 women special seat councilors).

\subsection{Data Collection Methods}

Both primary and secondary data were collected. Primary data were collected using interviews, questionnaires and focus group discussion; on the other hand, secondary data were collected from full council meeting minutes, standing committees' minutes, and council management team meeting minutes. This method involved direct consultation with employees' especially top management and a list of councilors of the Bukoba Municipal Council for the aim of finding facts and opinions on how conflicts are managed in the council. Also, electronic sources and other documents obtained in the study area were used to get more secondary data. 


\section{Findings of the Study}

The study used both quantitative and qualitative research methods. Content analysis was used to analyze qualitative data which were obtained from interviews and Focus Group Discussion; and quantitative data were analyzed using Microsoft Excel Spread sheet and presented in form of tables, charts and percentages.

\subsection{Types of Conflict at BMC}

The findings from this study revealed that; there were different conflicts in Bukoba Municipal Council. The notable conflicts found in the study area were four including the following: conflict between councilors and employees of local government authorities; conflict between opposition parties' councilors and councilors from ruling party; elected (ward) councilors and women councilors from special seats; conflicts among employees themselves.

\subsubsection{Conflict between Councilors and Employees}

This is one of the big conflicts found at BMC; where councilors who are decision makers via council standing committees; in most cases do not agree with technical advice from employees (Heads of departments and Units) in areas which do not favour their interests. For instance; councilors in one of the meetings were pushing to reallocate funds from planned projects to another projects or donor funds to be used for paying allowances and other activities, which were not planned and budgeted at the beginning of the year or are not activities targeted by the donor fund. As the Municipal Treasurer commented "councilors do not understand that, their priorities are taken care during budgeting and not otherwise; and donor funds have their directives on which projects should be used. It is unfortunate we are arguing for something which is very clear. For instance; you cannot use money from road fund for different activities rather than construction of roads. ${ }^{1}$

\subsubsection{Conflict between Opposition Parties' Councilors and Councilors from Ruling Part}

This also is another conflict, which was found at BMC; the council has six (6) councillors from opposition parties. The courses, which culminate to existing of these conflicts is during allocation of fund for development projects. It was revealed that, in most cases, councilors from ruling party do not like to see any fund located to the ward, whose councilor is from an opposition party. One councilor from the ruling party lamented; "hatuwezi kuwapelekea maendeleo upinzani; ni sawa na kukiua chama chetu; hatupeleki maendeleo huko ili wananchi wajue walikosea kuchagua upinzani, ili uchaguzi ukifika wasiwachague tena"2 which means that, we cannot allocate funds for development projects in opposition wards as that will boost them in next election; we want people to see that, they made a wrong choice in electing councillors from opposition parties.

\subsubsection{Elected (ward) Councillors and Special Seats Councillors}

This kind of conflicts was also found at BMC, which revealed that, the issues that facilitate

\footnotetext{
${ }^{1}$ Interview, Treasurer, BMC Headquarter, 10/09/2016

2 Councilor; name withheld; BMC Headquarter, 10/9/2016
} 


\section{Macrothink}

the existing of the conflicts were leadership of standing committees of the council. Despite the fact that there is no regulation which prohibits special seat councilors to be elected as chairperson of standing committees but the elected councilor to consider them as not proper candidates for those position. As one councilor commented "haiwezekani viti maalumu wawe wenyeviti wa kamati za kudumu; sisi tuliochaguliwa na wananchi ndio tunatakiwa tuziongoze hizi kamati"' which means that, special seat councilors cannot be elected as chair of standing committees but councilors representing wards as are responsible for planning and implementing wards projects. However; there are no regulations that prohibit special seat councilors to contest for chairmanship of standing committees; that is why; a standing committee of land and environment of BMC in one term was chaired by a special seat councilor.

\subsection{Causes or Sources of Conflict at BMC}

During the study, it was observed that the following are the causes of conflict between councilors and local government employees in BMC, such as different level of education, delay of project implementation, personal interest, negative attitude, poor communication, scarcity resources, and interference in work. For instance, one councilor lamented in Swahili language that,

"Hawa wakuu wa idara hatuna imani nao, wanafuja tu mali za manispaa, ndo maana miradi inachukua mda mrefu kutekelezwa..."4 which means that, councilors have no trust with heads of department as they believe probably are embezzling council fund for their own interest, that is why many projects are not well implemented or implementation do take long to be completed. The figure 4.1 below shows this result graphically.

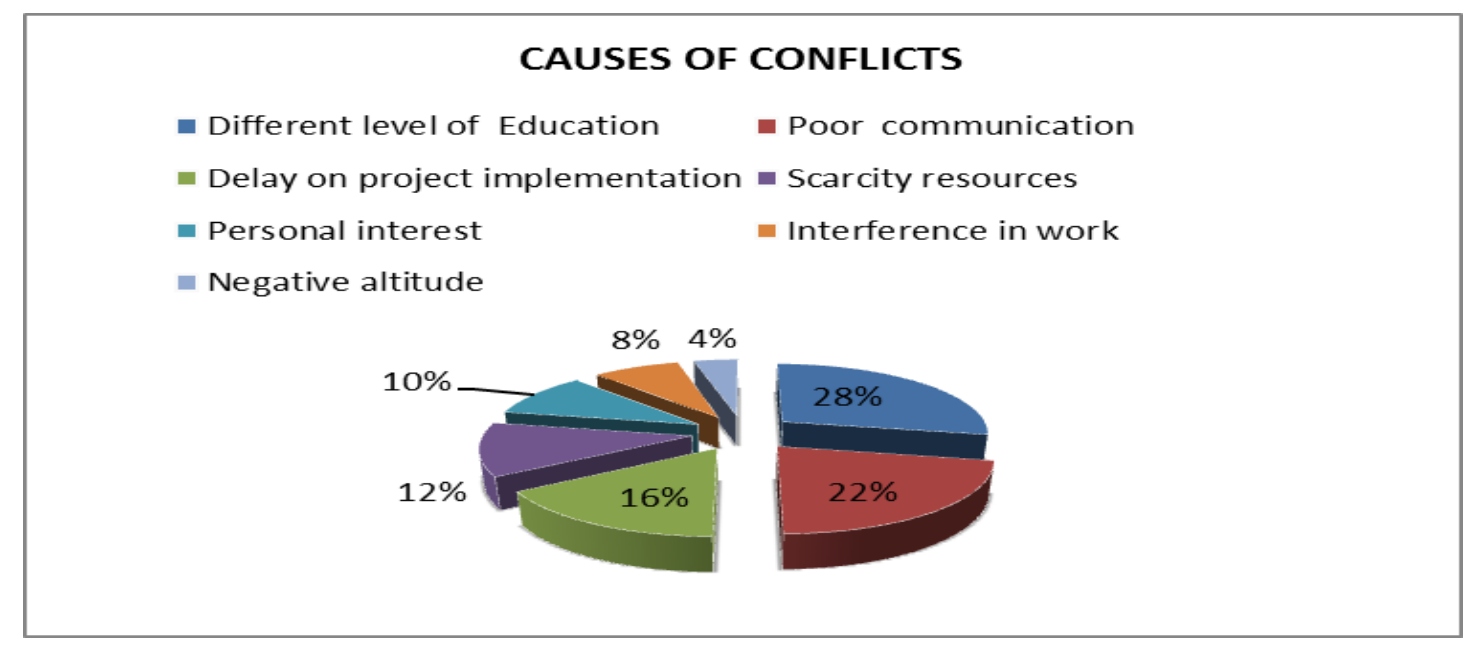

Source: Field data, 2016

Figure 4.1. Causes of Conflicts

\footnotetext{
3 Councilor; name withheld; BMC Headquarter, 10/9/2016

${ }^{4}$ Interview, Councilor, BMC Headquarter, 10/9/2016
} 


\subsubsection{Negative Attitude towards Each Other}

The study revealed that, there is negative attitude of council employees towards councilors, they believe that, councilors are not educated and are just there not to foster development but to serve their interest. For instance, one Head of department claimed that

"Because of their selfish interest, councilors are not ready to preside a meeting if their meeting allowances are not guaranteed by the Municipal director; and sometimes do delay the meeting for two to three days in order to get more allowances. These people are not here for the interest of their wards, but their personal interest". 5

This study supports those of Kunkuta (2003) that, conflict between permanent local government employee and councilors is due to most of councilors in Tanzania consider permanent local government employees to be stubborn, dishonest, corrupt and disrespectful while permanent local government employees regard councilors as illiterate with hard to understand what will take to achieve local development. Therefore, for local government to avoid this situation, much effort is needed to train councilors and local government employees to understand the key role of each actor. Demarcation of roles and responsibility, and working as a team, will help many local governments in Tanzania to move faster towards turning their vision into reality; by complimenting and not conflicting each other.

\subsection{The Upshots of Conflicts in Local Government Authorities}

The study revealed that; there are both negative and positive conflicts in local government authorities in Tanzania; as $63 \%$ of respondents confirmed this. During the study, the researcher also had interest to investigate on the effect of conflict between these two actors in Bukoba Municipal Council. In considering negative impacts of conflicts in Bukoba Municipal Council, the study revealed that, conflicts impact negatively developmental issues in the municipality such as delay in decision-making, poor allocation of resources, delay of project implementations, tense atmosphere between councilors and local government employees and many other related issues. The figure below 4.2 presents these findings graphically.

\footnotetext{
5 Interview, Head of Department, BMC, 11/09/2016
} 


\section{Whether there is negative impact of conflicts}

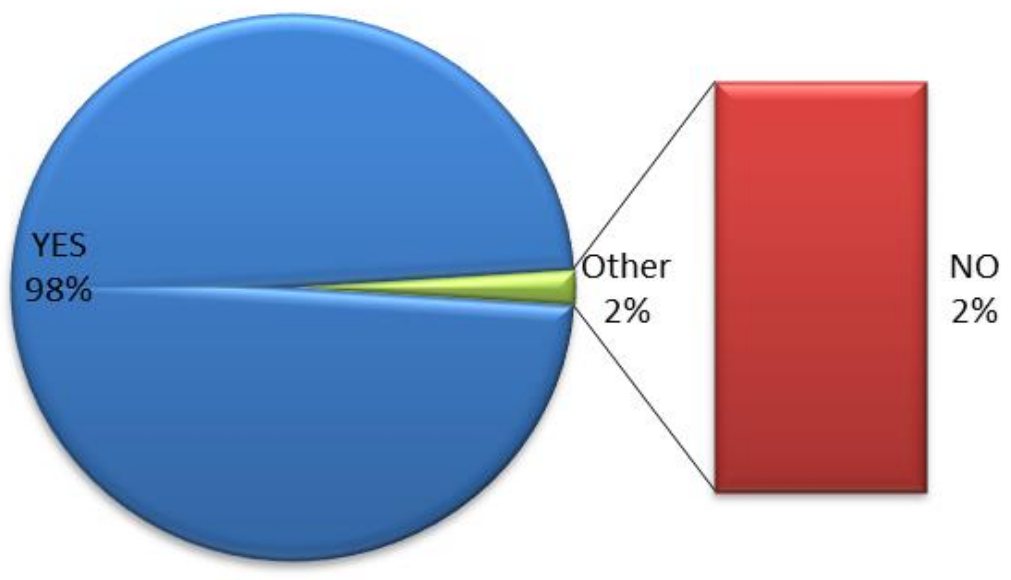

Source: Field data, 2016

Figure 4.2. Negative impact of conflict at BMC

In the table 4.2 shows that $49(98 \%)$ of the respondents out of 50 who responded to questionnaires were aware of negative effect of conflict between councilors and employees of Bukoba Municipal Council and 1(2\%) of respondents out of 50 who respond to questionnaire was not aware on negative effect of conflict between councilors and employees at Bukoba Municipal Council. As one employee complained that

"Conflicts are so bad, especially between councilors and Heads of departments, and when this happens, standing committees meetings are not effectively carried out, and when this happen, decisions are delayed and implementations of projects and programmes are delayed too; hence affects negatively the total service delivery in the municipality" 6

\subsection{The Negative Effect of Conflict in Local Government Authorities}

Given the negative connotation of conflicts, also, conflicts have direct negative effects to the development of Bukoba Municipal Council; and the following part explains in details the negative of effect of conflicts between councilors and local government employees in Bukoba Municipal Council. The figure 4.5 bellows shows these conflicts responses graphically.

\footnotetext{
${ }^{6}$ Interview, employee (name withheld), BMC Headquarter, 10/09/2016
} 


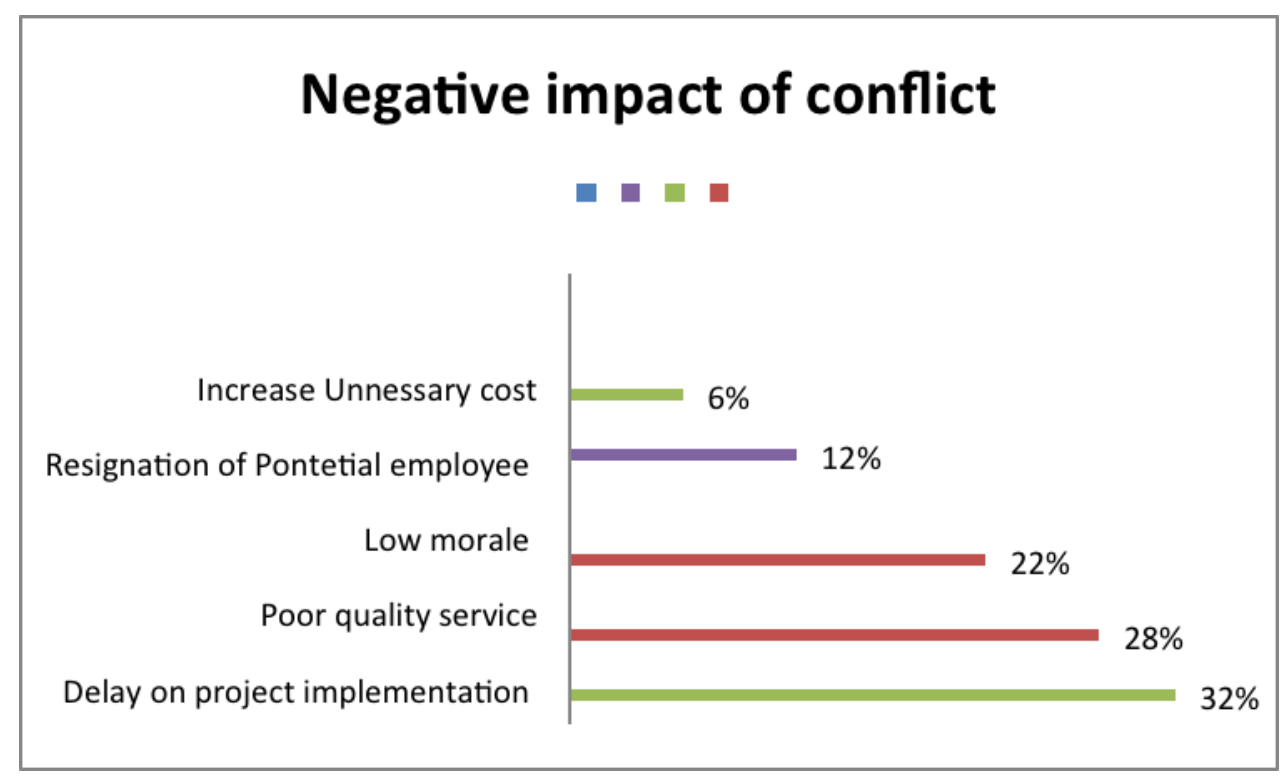

Sources: Field data, 2016

Figure 4.5. Negative impact of conflict

\subsubsection{Delay of Project Implementation}

In the figure 4.5 show that, 16 of respondent to questionnaire which was equal to (32\%) of total respondents in the study, pointed out that, delay of project implementation was the among of negative effect of conflict between councilors and employees in Bukoba Municipal Council, this was because of this actor spend a lot of time to solve conflict between them rather than give attention to developing project of the council. For example, Water Engineer was responsible to make sure that, the project of supplying water to selective village should be accomplished within the suggested time, however, the delay to accomplish the project was caused by conflict between him and councilors of other wards which were not selected for the project.

\subsubsection{Poor Quality of Services Delivery}

Also, poor services delivery to a society was among the negative effects of conflict between employees and councilors in BMC, due to stress and attention which employees had due to conflict occurred between them and councilors, facilitated employees to provided poor services because of low level of attention due to misunderstand that happened to them. This was supported by $28 \%$ of total respondent in study who mentioned this as a negative effect of conflict at BMC.

\subsubsection{Low Morale of Workers}

In this study, it was found that, conflict facilitated to low performance to workers because of misunderstanding existed between them and councilors, for example, interference of 
councilors to employees' day to day operations reduced their morale to perform better. This was noted by 11 respondents, equal to $(22 \%)$ of total respondent in the study, who pointed out the negative effect of conflict between councilors and permanent employees in Bukoba Municipal Council.

\subsubsection{Increase of Unnecessary Cost to the Council}

In this study, another negative effect of conflicts at BMC was an increase of unnecessary cost to the council, where the council used lot of money for resolving conflict in the municipality. The cost associated include for buying fuel and payment to those who were involve in solving conflicts. These cost in most cases were out council budget of the year. This was pointed out by 3 respondents, which were equal to $(6 \%)$ of total respondents in the study as negative effect of conflict between councilors and employees in Bukoba Municipal Council.

\subsubsection{Resignation of Potential Employees in Council}

This was declared by 6 respondents, which were equal to (12\%) of total respondents in the study as negative effect of conflict between councilors and employees in BMC Municipal Council. Due to misunderstanding existed between councilors and employees of BMC, it facilitated some of worker to write resignation letter from their employment which had potential effect in council to achieve its goals. For example, a teacher was having misunderstanding with councilor of particular ward which this teacher was among teachers who were needed much by that school he was teaching; hence due this misunderstanding he was forced to resign from teaching.

\subsection{Positive Impact of Conflict between Councilors and Employees in BMC}

In respect to positive impact of conflicts between councilors and employees of Bukoba Municipal Council, the findings reveled that; conflicts can enhance effective and efficient use of resources, can bring into open the clashing of interests, can forge good team work while negotiating in resolving conflicts; and further, can even improve communications between councilors and employees in local authorities. As one of the councilor reveled that,

"Nilikuwa na mgogoro na Mhandinsi wa Manispaa hii, alikuwa hajengi vizuri barabara za kwenye kata yangu, baada ya kufikishana kwenye kamati ya fedha, tuliwekwa sawa, na sasa ameweza kunijengea barabara nzuri, tena kwa kiwango cha rami" " which means that, the councilor had a conflict with Municipal Engineer of not constructing good roads in his ward, this let them to Finance committee where their difference was resolved, and the engineer managed to build good tarmac road in his ward. The figure below 4.3 shows this presentation graphically.

\footnotetext{
7 Interview, Councilor, Miembeni ward, BMC, 11/09/2016
} 


\section{awareness of positive effects of conflicts}

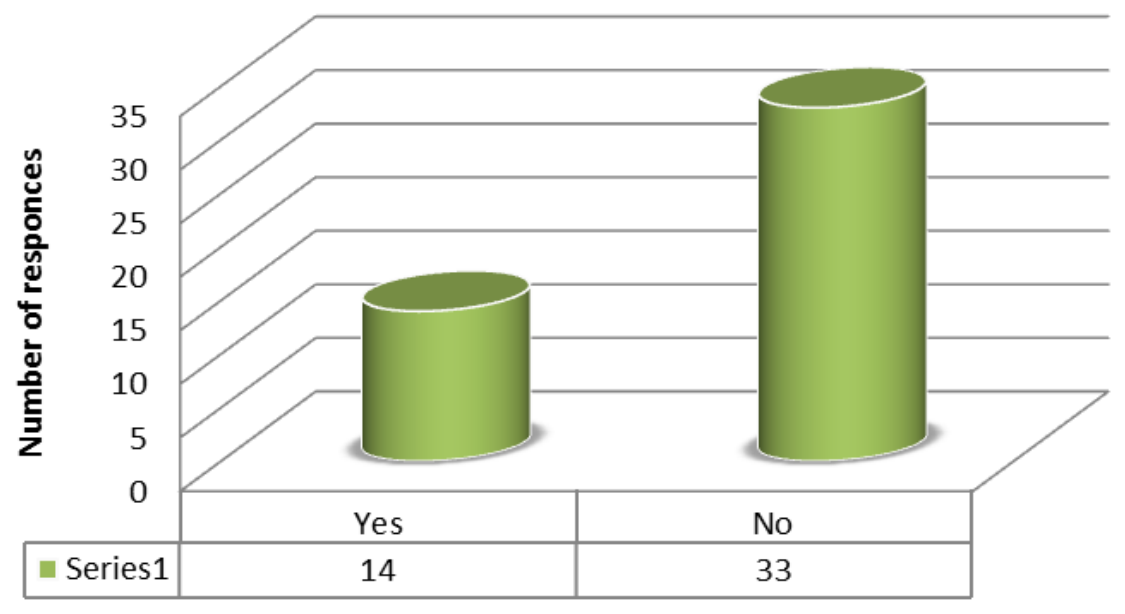

Source: Field data, 2012

Figure 4.3. Awareness of positive effects of conflicts

In the table 4.3 shows that $14(28 \%)$ of respondent out of 50 who respond to questionnaire and interview were aware on positive effect of conflict between councilors and employees of Bukoba Municipal Council and 36(72\%) of respondent out of 50 who respond to questionnaire were not aware on positive effect of conflict between councilors and permanent employees of Bukoba Municipal Council. However, conflicts can only bring good positive result if these conflicts are resolved in early stages for the health of the organization; as prolonged conflicts are always negative for the firm operations. Moreover, conflicts are not always bad to the organization, sometimes they have impacts which can positively improve service delivery especially in local authorities be the case in this study. The table below 4.1 gives detail in respect to five variables, which were subjected in this study.

Table 4.1. The positive effect of conflict at BMC.

\begin{tabular}{lll}
\hline Effect & Frequency & Percentage (\%) \\
\hline Increase morale to the workers & 18 & 36 \\
Improved service delivery & 16 & 32 \\
Problem notification & 11 & 22 \\
Timely project implementation & 5 & 10 \\
Total & 50 & 100 \\
\hline
\end{tabular}

Sources: Field data, 2016 


\subsubsection{Increase of Morale of Workers}

Table 4.1 shows that the positive effect of conflict which was an increase of morale of workers in performing their duties in the council, this was due to peaceful environment of working which motivated the employees to work effectively so as to achieve organization goals, this was pointed out by 18 respondents which was equal to (36\%) of total respondents in the study as positive effect of conflict between councilors and employees in Bukoba Municipal Council.

\subsubsection{Improved Services Delivery}

In the study was found that occurred conflict between two actors in the council was facilitated the council to delivery services in good way this because after resolution of misunderstanding the workers were regain capability of provide services effectively to their customers, this was noted by 16 respondents which was equal to $(32 \%)$ of total respondents in the study as positive effect of conflict between councilors and employees in Bukoba Municipal Council.

\subsubsection{Problem Notification in the Council}

Also another positive effect of conflict between councilors and employee of BMC was problem notification in the council, among of 11 which was equal to (22\%) of total respondents in the study as positive effect of conflict between councilors and employees in Bukoba Municipal Council this was due to the fact that occurrences of misunderstanding between this two actors facilitate the council to be aware and to recognize that there the problem such delay of project to be implemented hence to take positive solution on it.

\subsubsection{Timely Project Implementation}

In the study, also study found that, there were existence of misunderstanding between councilor and employees of BMC facilitate the responsible employee to perform their given duties timely because of the challenge they were facing by being in collision with councilors, this was pointed out by 5 respondents which was equal to (10\%) of total respondents in the study as positive effect of conflict between councilors and employees in Bukoba Municipal Council.

\subsection{Mechanisms Used to Solve Conflicts in Local Government Authorities}

The study also investigated different mechanisms used by Local Government Authorities to solve misunderstandings between councilors and permanent employees. 


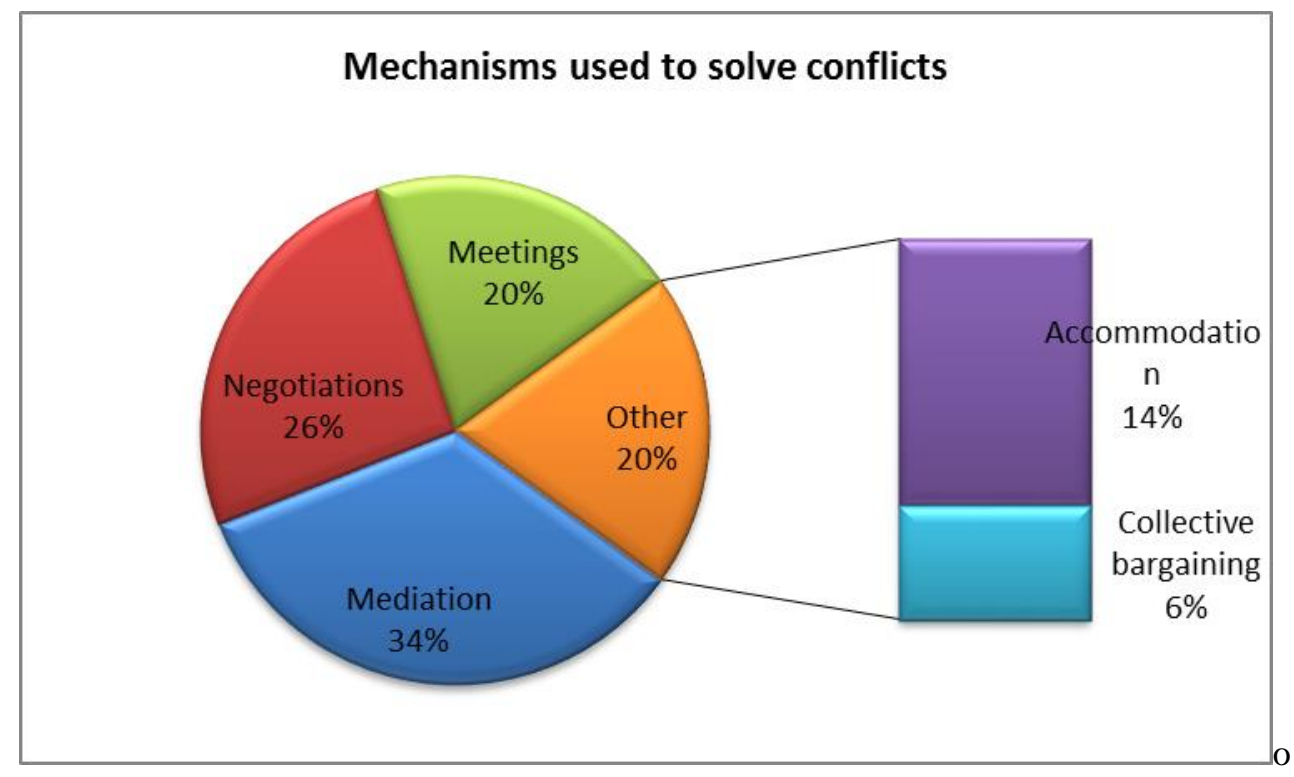

Source: Field data, 2016

Figure 4.6. Mechanisms used to solve conflicts

The study revealed that, there are different strategies used to solve conflicts at Bukoba Municipal council; and those strategies are discussed in detail below:

\subsubsection{Mediation}

Mediation is a voluntary process in which an impartial person (the mediator) helps with communication and promotes reconciliation between the parties, which will allow them to reach a mutually acceptable agreement. Mediation often is the next step if negotiation proves unsuccessful. This was mentioned by 17 respondents which was equivalent to (34\%) of total respondents in the study, as the method to solve conflict, mediation was the process which involved third party who influences the parties in disputes to come into agreement on matter which made them to collide. The mediator helps the parties think outside of the box for possible solutions to the dispute, broadening the range of possible solutions.

\subsubsection{Negotiations}

This is the method of solving conflicts where by the actors in disputes meet together in order to resolve their differences, misunderstanding, and to reach agreement. 13 respondents which was equal to $(26 \%)$ of total respondents declared this as mechanism for conflict resolution at the council. Negotiations was one of the way used at BMC to resolve conflict between councilors and employees, this was due to the fact that, through this method parties made their own decision and reach their own agreement, also this method resulted to win-win solution. Negotiation allows actors to participate directly in decisions that affect you. In the most successful negotiations, the needs of both parties were considered. 


\subsubsection{Meetings}

This means a gathering of two or more actors at which some issues are discussed so as to get into conclusion. This was pointed out by $10(20 \%)$ of total respondent in the study as one of mechanism used to solve conflicts at BMC, actors (employees/councilors) met and showed their grievances; and hence came into agreement. Meeting helped to enhances good relationship between the parties. The study also found that, meeting is among the most used method by the council as it takes short time and easier mechanism for conflict resolution. This was further lamented by one of the councilor who said that

“mikutano na semina za mafunzo ya kuongeza uwezo zinasaidia sana kubolesha na kupunguza migogogro; ambapo madiwani hufundishwa majukumu yao na hivyo kupunguza muingiliano na watendaji wa halmashauri. Mafunzo ya utawala bora yanasaidia sana pia kupunguza migogoro'8 means that, meeting and training in form of seminar and workshop to councilors help a lot to reduce conflicts, as councilors are trained their roles and responsibilities and hence reduce interference with local government employees in discharging their duties.

\subsubsection{Collective Bargaining}

This is the method of resolving conflicts where the representative of each group comes together with mandate to work out for the solution collectively. In respect to this, 3(6\%) of the respondents asserted that, collective bargaining was used by BMC to resolve conflicts when emerged. This method is normally used due to being an integrative solving problem method, which promotes cooperation among employees and also with the management and councilors at BMC.

\subsubsection{Accommodation}

This is method of conflict resolution whereby group in conflict concentrated on current issues at hand and put their difference aside until later time. This was pointed out by 7(14\%) of total respondents in this study as the method used solve conflict between councilors and employees; where the actors in friction had to put aside any conflict in order to continue with the activities facing them and later solve their conflicts for the benefit of all group in the council.

\section{Conclusions and Recommendations}

Conflicts are inevitable as they are naturally occurring phenomena with both negative and positive effects on the council and all actors involved. The noticeable causative factors for friction between councilors and employees are scarcity resources, poor communication, gaps in education levels, personal interests, interference in duties, execution of projects, delay in project implementation and negative attitude between these actors. Conflicts between councilors and employees of BMC had negative effect such as increase of unnecessary costs,

\footnotetext{
${ }^{8}$ Interview, councilor, Nyanga ward, BMC, 11/09/2016
} 


\section{Macrothink}

Journal of Public Administration and Governance

ISSN 2161-7104

2017, Vol. 7, No. 3

low of morale to workers, delay in project implementation, and poor services delivery. However, these conflicts had a positive effect to BMC, such as problem notifications, increase morale and improve service delivery that led to high performance and improves service delivery in municipality. The problem between councilors and employees at BMC were resolved using different methods such as committees, mediation, collective bargaining, negotiation and accommodation.

The study recommends that, there should be transparency and accountability during execution of their duties and entire business in the council so as to avoid friction on mistrust among them; the council should conduct meetings frequently so as to identify different problems which exist in the council before they bring damage to the council, this will help the council to be up to date on any problem which the organization may encounter and avoid it timely; the council should have proper flow of information sharing on different matters concerning the council such as distribution of council finances and their expenditure so as to avoid conflicts over the use of council funds towards funding different expenditures.

\section{References}

Clarke, M. (1999). General management in local government: getting the balance right. London: Longman.

Darling, J. R., \& Walker, W. F. (2001). Conflict management: Use of the behavioral style (model). Leadership and organization development journal, 22(516), 230-242. https://doi.org/10.1108/01437730110396375

Greenberg, J. (1999). Managing behavior in organization, 2nd Edition, prentice -hall.

Hughes, C. (2001). An investigation of conflict management in Cambodia villages. University of Cambodia: Centre for Development Research.

Jaffee, D. (2008). Conflict at work throughout the history of organization, New Delhi, vikas publishing house limited.

Johson, R. (2004). Human behavior in Multi-culture organization, London, Thomson custom publishing.

Kunkuta, G. (2003). Training programme on Good Governance for Councilors and Staff, Kilombero District Council. Morogoro: Mzumbe Institute of Public Administration.

Mishran, N. (2001). Organization behavior, New Delhi, vikas publishing house limited.

Newton, W. (2002). Organization behavior and Human behavior at work, London, Oxford University

Pareck, U. (2002). Understanding organization behavior, $2^{\text {nd }}$ Edition, London, Oxford University.

Pondy, L. R. (2009). Organizational conflict: concepts and models. Administrative science quarterly, 31, 494-320. 


\section{Macrothink}

Journal of Public Administration and Governance ISSN 2161-7104 2017, Vol. 7, No. 3

Rummel, J. (1996). Understanding Conflict and Wars, $3^{\text {rd }}$ Edition, London, Prentice - Hall.

Robbins, P. \& Sanghi, S. (2006). Organization behavior, $7^{\text {th }}$ ed, Dorling Kindersley (pvt) limited.

\section{Copyright Disclaimer}

Copyright for this article is retained by the author(s), with first publication rights granted to the journal.

This is an open-access article distributed under the terms and conditions of the Creative Commons Attribution license (http://creativecommons.org/licenses/by/4.0/). 